\title{
Depressive symptoms in postpartum women at Family Health Units
}

Synara Barbosa de Melo 1

Rhayza Rhavênia Rodrigues Jordão 2

Fernanda Jorge Guimarães 3

Jaqueline Galdino Albuquerque Perrelli 4

Amaury Cantilino 5

Everton Botelho Sougey 6

1-4 Centro Acadêmico de Vitória. Universidade Federal de Pernambuco (CAV/UFPE). Rua Alto do Reservatório. s.n. Bela Vista. Vitória de Santo Antão, PE, Brasil. CEP: 55.608-680. E-mail: jaquelinealbuquerqueufpe@gmail.com

5,6 Universidade Federal de Pernambuco. Recife, PE, Brasil.

\begin{abstract}
Objectives: to identify postpartum depression among women assisted by Family Health Units (FHU).

Methods: this is a cross-sectional study with a quantitative approach carried out in FHUs at the city of Vitoria de Santo Antão - PE. Fifty eight mothers constituted the sample. We used the Portuguese version of the Postpartum Depression Screening Scale-PDSS for screening. We collected data from February to April 2011.

Results: we were able to demonstrate that $8.6 \%$ of participants had scores above the PDSS cut-off point. We also found an association between postpartum depression and incomplete primary education.

Conclusions: although the percentage of women with postpartum depression scores is lower than values found in other national studies, the early identification of these mothers in FHU is imperative, given the harmful repercussions that depression can cause in women, as well as in physical and psychic development of the baby.
\end{abstract}

Key words Postpartum depression, Mental health, Postpartum period 


\section{Introduction}

Pregnancy and postpartum are processes that causes profound transformations in women's lives, such as social, cultural, physiological and especially emotional changes; being the first days after delivery carried with strong emotions and new challenges in the process of becoming a mother. ${ }^{1}$ Such transformations, overall hormonal ones, influence women's mental health. Besides, socio-cultural, family and personal charges related to adequate development of maternal functions arise. All these factors create stress, intense physical and emotional exhaustion in women.2-5

Moreover, the modern western society built a common stereotype over the years about motherhood from a romantic and fanciful perspective. In this ideal, after one child is born, the woman will feel complete happiness and fulfillment, and she should care and love her child automatically, making sacrifices in favor of her offspring. 6,7 However, more recently, the maternal behavior has also been discussed from a social construction perspective, from the conception that being woman does not necessarily imply having an innate and programmed maternal instinct. In the contrary, these women become mothers after their child is born, from their individual experience with the world and her baby. 5,8

Thus, the mother-baby relationship is built considering her experiences which are previous to pregnancy, resilience, as well as the baby's behavior. Life story, relationships, support from a partner in baby's care and pregnancy planning are factors that interfere in building a bond with the baby. This relationship strengthens as the mother deals with conflicts and adapts herself to her changes during the postpartum period. 9 When there are dysfunctions in this adaptation, there is a substantial increased chance of postpartum woman to develop some mental disorder.

Within mental disorders presented in the postpartum period, Postpartum Depression (PPD) is a psychopathological case of extreme public health relevance, as it can affect up to $25 \%$ of women. $3,12,13$

It is a mood disorder characterized by irritability, anxiety, lack of motivation, lack of energy or psychomotor agitation, long-lasting sadness, low self-esteem, crying crises, feeling of guilt, lack of interest in the baby, changes in appetite, sleep patterns and the feeling of not being capable to care for the child, which can evolve to suicidal ideation. Also, other clinical manifestations of physical nature can be observed in these women, as: headache, bleeding, lactation difficulties with the presence of fissures and infections, within others. $3,4,10$

Regarding repercussions to the child's health, other authors verified that babies who lived in a maternal depression context presented insecure attachment, less exploring of the environment, irregular sleep pattern, low self-esteem, anxiety and, higher likelihood to develop depression at adult age. 14 Therefore, there is a need to include PPD in discussions about maternal and infant mental health, as it is a prevalent disorder among women and puts motherhood and childhood development at risk.

From this perspective, there is a need to identify women who are in risk for PPD development early. The benefits of depression screening among pregnant and postpartum women in primary health attention are related with the reduction of depressive symptoms in women suffering from depression and the identification of those who need a more detailed assessment and treatment. 15 Therefore, this study aimed to identify PPD in women assisted in Family Health Units (FHUs).

\section{Methods}

We conducted a descriptive, cross-sectional study with a quantitative approach. Women enrolled in four FHUs at the city of Vitória de Santo Adão- PE composed the population. To estimate the sample, we used a formula for studies with finite population, as:

$$
\mathrm{n}=\frac{\mathrm{Z}_{\alpha}^{2} \cdot \mathrm{P} \cdot \mathrm{Q} \cdot \mathrm{N}}{\mathrm{e}^{2}}
$$

were:

$-Z_{\alpha}^{2}=1.96$ (confidence interval of $95.0 \%$ );

- Proportion of occurrence of the phenomenon of interest $=13.3 \%(0.133)^{16}$;

- Sampling error $=8.7 \%$;

Thus, the sample was estimated in 58 women who were consecutively selected in a way that they attended the following pre-established inclusion criteria: postpartum women aged between 18 and 49 years, literate, who were between two and 26 postpartum weeks. The only exclusion criterion was the baby's death during the data collection period.

We collected the data between February and April of 2011 during childcare consultation, in a private environment, to guarantee privacy and information secrecy. To obtain data, we used a socioeconomic questionnaire and a PPD screening scale called Postpartum Depression Screening Scale (PDSS), developed by Beck and Gable. 17

The scale has 35 items with Likert-type answers 
distributed in seven dimensions: sleeping/eating disturbances; anxiety/insecurity; emotional lability; cognitive impairment; loss of self; guilt/shame; and contemplating harming oneself. 16 Each scale dimension has five items related with the feelings of a mother after her baby's birth. Postpartum women are invited to indicate their level of disagreement or agreement with each scale item from 1 (strongly agree) to 5 (strongly disagree), intended to assess women's concerns during postpartum period. 16

The PDSS was chosen for this study because it has specific items about the relationship between mother and baby during postpartum and its high reliability $(\alpha=0.95)$, sensitivity and specificity to screen PPD in women. Besides, the instrument validation occurred in Recife - PE with a sample of 120 postpartum women and, therefore, it is close from the reality of participants of our study. The better cut-point to suggest PPD found in this validation study was 102,16 being this score the parameter used in our research to indicate suggestive cases of postpartum depression.

Postpartum women were invited to participate in the study and those who accepted, signed the Free and Informed Consent Term. We guaranteed participant's anonymity and that the collected information would be used only for scientific purposes without the participant's identification.

We organized the data in a Excel version 2007 spreadsheet and we analyzed them using the statistical package SPSS version 17.0. We calculated descriptive statistics (absolute and relative frequencies; mean and standard deviation) and verified the association between the suggestive cases of PPD and the following variables: age, marital status, number of children, desired pregnancy, education, paid activity and monthly family income. We used the Chi-Square test for frequencies lower than 20 and higher than five, and the Fisher's Exact test for expected frequencies lower than five. We applied the level of significance $(\alpha)$ of 0.05 in all analyses.

The project was approved by the Ethics Committee in Research with human beings from the Health Sciences Center of Federal University of Pernambuco (UFPE), under the protocol 324/2011. We respected all ethical aspects by the resolution $\mathrm{n}^{\circ}$ $466 / 2012.11$

\section{Results}

The mean age of postpartum women was 22.55 $( \pm 5.59)$ varying from 18 to 38 years. A percentage of $46.6 \%$ declared to be in a stable relationship and
$43.1 \%$ were married. Regarding education, $41.4 \%$ of women completed high school. About family income, $43.1 \%$ referred to a monthly income higher than two minimum wages and approximately $56.9 \%$ did not perform paid activity.

Regarding obstetric history, the average of children was $2.45( \pm 0.68), 86.2 \%$ desired the pregnancy and $17.2 \%$ reported losing a child. Spontaneous abortion was the most cited cause $(70.0 \%)$.

About the depressive symptoms, scores varied from 38 to 126 with a mean of $73.42( \pm 18.61)$. A percentage of $8.6 \%$ of women presented a suggestive PPD case (scores above the cut-point of 102). PPD had a significant statistical association with the level of education "incomplete high school" ( $p=0.032$ Fisher's Exact test). The t-test for independent samples showed that women who did not complete high school had on average, higher scores for PPD ( $p=0.030$ - T-test for equality of means). All other variables were not associated with depression. Table 1 shows the descriptive data of items composing the PDSS, according to its dimensions.

Regarding the changes in the sleep/eating dimension, we observed that $36.2 \%$ had difficulties to sleep even when their babies were asleep, $31.0 \%$ affirmed loss of appetite, the same percentage reported to spontaneously wake up in the middle of the night and to have trouble going back to sleep, $22.4 \%$ rolled in bed for a very long time during the night trying to fall asleep and, $27.6 \%$ knew that they needed to eat, but they were not able to.

In the dimension anxiety/insecurity, $20.7 \%$ of mothers reported loneliness, $18.9 \%$ felt oppressed, $27.5 \%$ scared, $60.3 \%$ anxious with the smallest things that had to do with their baby and, $22.4 \%$ presented restlessness.

Regarding the dimension emotional lability, $31.0 \%$ reported to cry a lot without motive, $37.9 \%$ felt mood swings and, $43.1 \%$ presented irritability. On the other hand, $84.5 \%$ affirmed to be happy and $81.0 \%$ did not feel anger during the postpartum period.

About cognitive impairment, the difficulty to concentrate was present in about $38.0 \%$ of women. Regarding the loss of self-dimension, $31.0 \%$ referred the fear of never becoming again who they were before. The feelings of guilt/shame and suicidal thoughts were not frequent. 
Table 1

Description of depressive symptoms, according to PDSS dimensions, present in postpartum women of Family Health Units (FHU). Vitória de Santo Antão, 2011.

\begin{tabular}{|c|c|c|c|c|c|c|c|c|c|c|}
\hline \multirow[t]{2}{*}{ PDSS Dimensions/ Depressive Symptoms } & \multicolumn{2}{|c|}{ SD } & \multicolumn{2}{|c|}{ D } & \multicolumn{2}{|c|}{ NDNA } & \multicolumn{2}{|c|}{ A } & \multicolumn{2}{|c|}{ SA } \\
\hline & $\mathrm{n}$ & $\%$ & $\mathrm{n}$ & $\%$ & $\mathrm{n}$ & $\%$ & $\mathrm{n}$ & $\%$ & $\mathrm{n}$ & $\%$ \\
\hline \multicolumn{11}{|l|}{ Dimension: Sleeping/Eating disturbances } \\
\hline Difficulty to sleep & 18 & 31.0 & 19 & 32.8 & 0 & 0.0 & 15 & 25.9 & 6 & 10.3 \\
\hline Loss of apetite & 23 & 39.7 & 16 & 27.6 & 1 & 1.7 & 12 & 20.7 & 6 & 10.3 \\
\hline \multicolumn{11}{|l|}{ To wake up in the middle of the night and have } \\
\hline difficulty to fall back asleep & 19 & 32.8 & 20 & 34.5 & 1 & 1.7 & 14 & 24.1 & 4 & 6.9 \\
\hline Difficulty to fall asleep & 24 & 41.4 & 19 & 32.8 & 2 & 3.4 & 11 & 19.0 & 2 & 3.4 \\
\hline Difficulty to eat even knowing it was necessary & 26 & 44.8 & 15 & 25.9 & 1 & 1.7 & 11 & 19.0 & 5 & 8.6 \\
\hline \multicolumn{11}{|l|}{ Dimension: Anxiety/Insecurity } \\
\hline Feeling of loneliness & 21 & 36.2 & 25 & 43.1 & 0 & 0.0 & 8 & 13.8 & 4 & 6.9 \\
\hline Feeling of oppression & 26 & 44.8 & 20 & 34.5 & 1 & 1.7 & 10 & 17.2 & 1 & 1.7 \\
\hline Feeling scared & 19 & 32.8 & 22 & 37.9 & 1 & 1.7 & 14 & 24.1 & 2 & 3.4 \\
\hline Anxiety with the smallest things related to the baby & 13 & 22.4 & 9 & 15.5 & 1 & 1.7 & 29 & 50.0 & 6 & 10.3 \\
\hline Restlessness & 15 & 25.9 & 29 & 50.0 & 1 & 1.7 & 10 & 17.2 & 3 & 5.2 \\
\hline \multicolumn{11}{|l|}{ Dimension: Emotional lability } \\
\hline Cry without an apparent reason & 24 & 41.4 & 15 & 25.9 & 1 & 1.7 & 12 & 20.7 & 5 & 10.3 \\
\hline Fear to not be happy again & 29 & 50.0 & 20 & 34.5 & 3 & 5.2 & 4 & 6.9 & 2 & 3.4 \\
\hline Mood swings & 21 & 36.2 & 12 & 20.7 & 3 & 5.2 & 17 & 29.3 & 5 & 8.6 \\
\hline Irritation & 14 & 24.1 & 18 & 31.0 & 1 & 1.7 & 21 & 36.2 & 4 & 6.9 \\
\hline Anger at an explosion level & 26 & 44.8 & 21 & 36.2 & 1 & 1.7 & 5 & 8.6 & 5 & 8.6 \\
\hline \multicolumn{11}{|l|}{ Dimension: Cognitive impairment } \\
\hline Lack of concentration & 20 & 34.5 & 22 & 37.9 & 3 & 5.2 & 12 & 20.7 & 1 & 1.7 \\
\hline Feeling of losing reason & 34 & 58.6 & 19 & 32.8 & 1 & 1.7 & 4 & 6.9 & 0 & 0.0 \\
\hline Feeling of becoming crazy & 26 & 44.8 & 22 & 37.9 & 2 & 3.4 & 7 & 12.1 & 1 & 1.7 \\
\hline Difficulty to make simple decisions & 25 & 43.1 & 24 & 41.4 & 1 & 1.7 & 7 & 12.1 & 1 & 1.7 \\
\hline Difficulty to concentrate in a task & 19 & 32.8 & 21 & 36.2 & 2 & 3.4 & 10 & 17.2 & 6 & 10.3 \\
\hline \multicolumn{11}{|l|}{ Dimension: Loss of self } \\
\hline Impaired self-perception & 34 & 58.6 & 21 & 36.2 & 0 & 0.0 & 2 & 3.4 & 1 & 1.7 \\
\hline Feeling of becoming a stranger to myself & 29 & 50.0 & 23 & 39.7 & 1 & 1.7 & 4 & 6.9 & 1 & 1.7 \\
\hline Fear of not coming back to be who I was before & 14 & 24.1 & 23 & 39.7 & 3 & 5.2 & 13 & 22.4 & 5 & 8.6 \\
\hline Feeling abnormal & 30 & 51.7 & 20 & 34.5 & 2 & 3.4 & 5 & 8.6 & 1 & 1.7 \\
\hline Feeling of nihilism & 30 & 51.7 & 21 & 36.2 & 1 & 1.7 & 4 & 6.9 & 2 & 3.4 \\
\hline \multicolumn{11}{|l|}{ Dimension: Guilt/Shame } \\
\hline Feeling failure as a mother & 33 & 56.9 & 17 & 29.3 & 1 & 1.7 & 6 & 10.3 & 1 & 1.7 \\
\hline Feeling that other mothers are better than me & 27 & 46.6 & 22 & 37.9 & 0 & 0.0 & 6 & 10.3 & 3 & 5.2 \\
\hline Feeling guilt for not loving my baby as I should & 29 & 50.0 & 21 & 36.2 & 1 & 1.7 & 3 & 5.2 & 4 & 6.9 \\
\hline Feeling shame of thoughts and feelings related to the baby & 24 & 41.4 & 20 & 34.5 & 3 & 5.2 & 7 & 12.1 & 4 & 6.9 \\
\hline Feeling worthlessness as a mother & 29 & 50.0 & 22 & 37.9 & 1 & 1.7 & 4 & 6.9 & 2 & 3.4 \\
\hline \multicolumn{11}{|l|}{ Dimension: Contemplating harming oneselfs } \\
\hline Thought that life would be better if I was dead & 41 & 70.7 & 13 & 22.4 & 0 & 0.0 & 1 & 1.7 & 3 & 5.2 \\
\hline Thought that death is the only alternative for the situation & 38 & 65.5 & 18 & 31.0 & 0 & 0.0 & 1 & 1.7 & 1 & 1.7 \\
\hline Desire of self-directed violence & 40 & 69.0 & 16 & 27.6 & 0 & 0.0 & 1 & 1.7 & 1 & 1.7 \\
\hline Feeling that the baby would be better without me & 37 & 63.8 & 19 & 32.8 & 1 & 1.7 & 0 & 0.0 & 1 & 1.7 \\
\hline Desire to disappear & 30 & 51.7 & 17 & 29.3 & 0 & 0.0 & 8 & 13.8 & 3 & 5.2 \\
\hline
\end{tabular}

PDSS= Postpartum Depression Screening Scale; SD= Strongly disagree; $\mathrm{D}=$ Disagree; NDNA= Neither disagree nor agree; $\mathrm{A}=\mathrm{Agree} ; \mathrm{AS}=\mathrm{Strongly}$ agree. 


\section{Discussion}

Young women, who had a partner, completed high school, with monthly income higher than two minimum wages composed the sample. Most of them did not perform any paid activity before the pregnancy and postpartum period.

A systematic review about PPD screening scales showed a mean age of revised studies varying from 15 to 30 years, $50.0 \%$ to $97.0 \%$ were married or in a stable relationship, $35.0 \%$ to $44.0 \%$ completed high school and the identified percentage of abortion varied from 2.9 to $50 \%$. These results were similar to the ones found in our study. 18

The scores suggestive of PPD were found in $8.6 \%$ of women. This percentage is lower than findings of the PDSS validation study in Brazil with a sample of women from Pernambuco, which results showed $16.7 \%$ with scores above the cut-point of 102.16 The same study found a PPD prevalence of $13.3 \%$, using another diagnostic tool. Another systematic review 19 assessed the magnitude of this disorder in Brazil and found a prevalence varying from $7.2 \%$ and $39.4 \% 21$ depending on the criteria and instruments used for detection.

An American study found high prevalence of depressive symptomatology during postpartum in 984 mothers $(63.0 \%)(\mathrm{n}=1.566$ women) using the PDSS.22 The presented percentages show the magnitude of this problem in national and global terms, and they signal the need of early interventions, above all, in the primary attention scenario.

About the risk factors for PPD, authors affirm that low socio-economic conditions, such as low income and low education level, can contribute to the appearance of this pathology.23,24 The sample of this study is composed by women in unfavorable economic situation and with low education level. Additionally, this study found a statistically significant relationship between the PPD and incomplete high school, therefore corroborating with findings of cited investigations.

The other socio-economic variables were not associated with depression. Recent studies did not find a significant relationship between the PPD diagnosis and variables as education time, family income and marital status. $12,13,25$

In what concerns sleep/appetite changes resulted from PPD, the results of this study are similar to results of another study that showed $29.7 \%$ of participants with difficulties to sleep, $20.8 \%$ mentioned loss of appetite, $31.7 \%$ woke up spontaneously in the middle of the night and presented difficulties to go back to sleep, $27.7 \%$ reported to roll in bed for a long time at night trying to fall asleep and, $23.8 \%$ knew they had to eat, but they were not able to. ${ }^{26}$

Changes during the postpartum period, the overload of attributions (mother, wife, housewife), high motherhood expectations from the woman and her family, lack of social and family support interfere in the woman's ability to develop the mother role. In this period, they feel tired, fatigued and tend to not taking care of themselves and spend all their energy caring for the baby, presenting appetite and sleep alterations, within other changes. ${ }^{20}$

The sleep interruption correlates with postpartum depressive symptoms. This sleep fragmentation negatively interferes in the wellbeing of both woman and baby, in the motherhood and breastfeeding, as well as in the child's health and development. The adequate sleep during post-partum favors the woman's health and her competence to develop her role as the child's caregiver. 27

Regarding anxiety/insecurity, postpartum women can develop an excessive concern about their baby's health and development, in such exaggerated way that she feels incapable and more susceptible to increase her depressive state. Maternal depression and anxiety negatively reflect in child development and they can cause harms in personal relationships that the child can develop during life. 28

The PPD consequences for both mother and baby relationship are concerning, as they compromise physical and mental health in a crucial moment of their lives. Depressive symptoms can change the woman's self-perception and can create conflicts in family relationships. Thus, it can impair the execution of attributions inherent to maternity, and as consequence, interfere in the performance of caring for the baby. 29

Besides, postpartum women frequently report complaints of tiredness, cry, and irritation. ${ }^{20}$ Data found in the present study corroborate with these findings, once in the emotional lability dimension, irritability, cry and emotional instability were the most cited.

In the dimension loss of self, $31.0 \%$ of mothers reported not to be themselves anymore. These feelings are related to high expectations in the maternity context and they can trigger feelings of fragility about themselves, of failure, deception, shame or disgust. 5

Suicidal thoughts were not frequent in our study. Symptoms related to depression in postpartum women are easy cry, irritability, bad mood, fatigue, 
feelings of guilt, sadness and depression. However, although suicidal ideation is not a typical symptom, a study showed a prevalence of $11.5 \%$ of suicide risk during puerperium and affirmed that low education level and presence of psychiatric disorders, including depression, are significant risk factors for suicide. 30

Facing the issue addressed in this study, we observed that although depressive symptoms suggestive of PPD are present in a reduced number of postpartum women, the most altered dimensions, sleep/appetite and emotional lability, substantially interfere in women's capacity to satisfactory perform motherhood. These result in mental suffering and anguish. In addition, women live surrounded by charges about their role as a mother and, sometimes, they do not have an adequate social support to help them perform this attribution.

Thus, the assistance to woman during the pregnancy-postpartum cycle needs to encompass the assessment of psychosocial factors, overall, depressive symptoms, due to its negative repercussions for mental health and the bond between mother and child.

The study revealed that $8.6 \%$ of postpartum women had scores suggestive of PPD and incomplete high school was associated with this phenomenon. The results provide aids for the health professional to plan care based on the early screening for this disorder, identifying the woman's and child's needs and the implementation of interventions, aiming at the promotion of the bond between mother and child and the identification of possible risk situations for PPD.

Additionally, we suggest the systematic use of robust screening instruments in primary health care and the PDSS appeared to be reliable and viable to early identify changes on women's mental health during postpartum period. As a study limitation, we point to reduced sample size and the conduction of the study in only four FHUs.

\footnotetext{
ERRATA:

In Page 164, Where it reads:

Methods

We conducted a descriptive, cross-sectional study with a quantitative approach. Women enrolled in four FHUs at the city of Vitória de Santo Adão- PE composed the population. To estimate the sample, we used a formula for studies with finite population, as:

$$
\mathrm{n}=\frac{\mathrm{z}_{\alpha}^{2} \cdot \mathrm{P} \cdot \mathrm{Q} \cdot \mathrm{N}}{\mathrm{e}^{2}}
$$

Reading:

We conducted a descriptive, cross-sectional study with a quantitative approach. Women enrolled in four FHUs at the city of Vitória de Santo Adão- PE composed the population. To estimate the sample, we used a formula for studies with infinite population, as:

$$
\mathrm{n}=\frac{\mathrm{z}_{\alpha}^{2} \cdot \mathrm{P} \cdot \mathrm{Q}}{\mathrm{e}^{2}}
$$
}

\section{References}

1. Pereira FM. Sintomas depressivos no puerpério: uma revisão de literatura. São Paulo: Marília; 2011

2. Gomes LA, Torquato VS, Feitoza AR, Souza AR, Silva MAM, Pontes RJS. Identificação dos fatores de risco para depressão pós-parto: importância do diagnóstico precoce. Rev Rene. 2010; 11:117-123.

3. Menezes FL, Pellenz NLK, Lima SS, Sarturi F. Depressão puerperal no âmbito da saúde pública. Saúde (Santa Maria). 2012; 38(1): 21-30.
4. Moraes MHC, Crepaldi MA. A clínica da depressão pósparto. Mudanças Psicologia da Saúde. 2011; 19 (1-2): 61-7.

5. Azevedo KR, Arrais AR. O mito da mãe exclusiva e seu impacto na depressão pós-parto. Psicol: Reflex Crit. 2006; 19 (2): 269-76.

6. Stellin RMR, Monteiro CFA, Albuquerque RA, Marques CMXC. Processos de construção de maternagem. Feminilidade e maternagem: recursos psíquicos para o 
exercício da maternagem em suas singularidades. Estilos Clín. 2011; 16 (1): 170-85.

7. Santos KD, Motta IF. The meaning of motherhood for three young mothers: a psychoanalytic study. Estud Psicol. 2014; 31 (4): 517-25.

8. Mesquita PAL, Fontes BFS, Oliveira Filho HB, Lopes LGF, Gonçalves MT, Moreira SRG, Pires do Rio SM. Trajetórias de mulheres que vivenciaram a gravidez/maternidade na adolescência. Mental. 2011; 9 (16): 443-89.

9. Strapasson MR, Nedel MNB. Puerpério imediato: desvendando o significado da maternidade. Revista gaúcha Enferm. 2010; 31(3): 521-528.

10. Cantilino A, Zambaldi CF, Sougey EB, Junior JR. Transtornos psiquiátricos no pós-parto. Rev Psiq Clín. 2010; 37 (6): 278-84.

11. Marcolan JF, Castro RCBR. Enfermagem em saúde mental e psiquiátrica: desafios e possibilidades do novo contexto de cuidar. 1 ed. Rio de Janeiro: Elsevier; 2013.

12. Guedes ACE, Kami CT, Cavalli LKV, Nicolaou SK, Hess VB, Maluf EMCP. Depressão pós-parto: incidência e fatores de risco associados. Rev Med. 2011; 90 (3): 149-54.

13. Morais MLS, Fonseca LAM, David VFL, Viegas M, Otta E. Fatores psicossociais e sociodemograficos associados à depressão pós-parto: um estudo em hospitais público e privado da cidade de São Paulo, Brasil. Estud Psicol. 2015; 20 (1): 40-9.

14. Santos LP, Serralha CA. Repercussões da depressão pósparto no desenvolvimento infantil. Barbarói. 2015; 43, p.526.

15. O'Connor E, Rossom RC, Henninger M, Groom HC, Burda BU. Primary Care Screening for and Treatment of Depression in Pregnant and Postpartum Women: Evidence Report and Systematic Review for the US Preventive Services Task Force. JAMA. 2016; 315 (4): 388-406.

16. Cantilino A, Carvalho JA, Maia A, Albuquerque C, Cantilino G, Sougey EB. Translation,Validation and Cultural Aspects of Postpartum Depression Screening Scale in Brazilian Portuguese. TranscultPsychiatry. 2007; 44 (4): 672-84.

17. Beck CT, Glade RK. Postpartum depression screening scale: development and psychometric testing. Nurs Res. 2000; 49 (5): 272-82.

18. Schardosim JM, Heldt E. Escalas de rastreamento para depressão pós-parto: uma revisão sistemática. Rev Gaúcha Enferm. 2011; 32 (1): 159-66.

19. Lobato G, Moraes CL, Reichenheim ME. Magnitude da depressão pós-parto no Brasil: uma revisão sistemática. Rev Bras Saúde Matern Infant. 2011; 11 (4): 369-79.
20. Cantilino A, Zambaldi CF, Albuquerque TLC, Paes JA, Montenegro ACP, Sougey EB. Depressão pós-parto em Recife - Brasil: prevalência e associação com fatores biossociodemográficos. J Bras Psiquiatr. 2010; 59 (1): 1-9.

21. Ruschi GEC, Sun SY, Mattar R, Chambô Filho A, Zandonade E, Lima VJ. Postpartum depression epidemiology in a Brazilian sample. Rev Psiquiatr Rio Gd Sul. 2007; 29 (3): 274-80.

22. Beck CT, Gable RK, Sakala C, Declercq ER. Postpartum Depressive Symptomatology: Results from a Two-Stage US National Survey. J Midwifery Women's Health. 2011; 56 (5): 427-35.

23. Gomes LA, Torquato VS, Feitoza AR, Souza AR, Silva MAM, Pontes RJS. Identificação dos fatores de risco para depressão pósparto: importância do diagnóstico precoce. Rev Rene. 2010; 11 (Esp.): 117-23.

24. Silva GA. Prevalência de depressão pós-parto em países desenvolvidos e em desenvolvimento: contribuições metodológicas de uma metanálise [tese]. São Paulo: Instituto de Psicologia, Universidade de São Paulo; 2013.

25. Figueira PG, Diniz LM, Silva Filho, HC. Características demográficas e psicossociais associadas à depressão pósparto em uma amostra de Belo Horizonte. Rev Psiquiatr Rio Gd Sul. 2011; 33 (2): 71-5.

26. Zubaran C, Foresti K, Schumacher MV, Amoretti AL, Muller LC, Thorell MR, White G, Madi JM. Validation of a screening instrument for postpartum depression in Southern Brazil. J Psychosom Obstet Gynecol. 2009; 30 (4): 244-54.

27. Bei DB, Milgrom PJ, Ericksen MJ, Trinder PJ. Subjective perception of sleep, but not its objective quality, is associated with immediate postpartum mood disturbances in healthy women. Sleep. 2010; 33 (4): 531-8.

28. Guidolin BL, Célia SAH. Sintomas depressivos e de ansiedade em mães durante internação pediátrica em um hospital universitário. Rev Psiquiatr Rio Gd Sul. 2011; 33 (2): $80-6$

29. Moura ECC, Fernandes MA, Rodrigues FI. Percepção materna sobre transtornos psiquiátricos no puerpério: implicações na relação mãe-filho. Rev Bras Enferm. 2011; 64 (3): 445-50.

30. Tavares D, Quevedo L, Jansen K, Souza L, Pinheiro R, Silva R. Prevalence of suicide risk and comorbidities in postpartum women in Pelotas. Rev Bras Psiquiatr. 2012; 34 (3): $270-76$.
Received on July 8, 2017

Final version presented on September 15, 2017

Approved on December 6, 2017 